\title{
A PROSPECTIVE OBSERVATIONAL STUDY OF MANAGEMENT PROTOCOL OF LOCALLY ADVANCED CARCINOMA RECTUM AT MGMMC AND MY HOSPITAL, INDORE
}

\author{
Kamlesh Ahirwar', Avinash Kumar Gautam²
}

1Senior Resident, Department of General Surgery, ESI Hospital, Indore, Madhya Pradesh, India.

${ }^{2}$ Senior Resident, Department of General Surgery, MGMMC and MY Hospital, Indore, Madhya Pradesh, India.

\begin{tabular}{l}
\hline ABSTRACT \\
BACKGROUND \\
Before 1900, Colon and Rectal cancer incidence was negligible. Following economic development and industrialisation, the incidence \\
of colorectal cancer has been rising dramatically. The vast majority $(98 \%)$ of colon and rectal cancers comprises of Adenocarcinomas. \\
Other rare rectal cancers included carcinoid $(0.4 \%)$, lymphoma $(1.3 \%)$ and sarcoma $(0.3 \%)$. Squamous cell carcinomas may develop \\
in the transition area from the rectum to the anal verge and are considered anal carcinomas. Very rare cases of squamous cell \\
carcinoma of the rectum have been reported. Approximately, $20 \%$ of colon cancers develop in the cecum.
\end{tabular}

\section{MATERIALS AND METHODS}

This is a prospective study of all patients with locally advanced carcinoma rectum seen at MY and Cancer Hospital, Indore. Between January 2011 and October 2012, 45 patients with rectal cancer were seen at MY and Cancer Hospital, Indore. Their age range was 20 - 75 years. The male/ female ratio was 1.3: 1. Fisher's exact test was applied for statistical analysis.

\section{RESULTS}

15 had abdominoperineal (AP) resection, 10 had anterior resection and 20 had tumours that were not resectable. 9 of the 15 patients $(60 \%)$ who had AP resection are alive till date, 6 died, while 10 out of the 10 who had anterior resection (100\%) are alive till date.

\section{CONCLUSION}

Patients with advanced rectal cancer should receive postoperative chemoradiotherapy. Local control, distant spread and survival improves when postoperative radiation therapy is combined with chemotherapy.

\section{KEY WORDS}

Locally Advanced Carcinoma Rectum.

HOW TO CITE THIS ARTICLE: Ahirwar K, Gautam AK. A prospective observational study of management protocol of locally advanced carcinoma rectum at MGMMC and MY Hospital, Indore. J. Evolution Med. Dent. Sci. 2018;7(21):2628-2633, DOI: $10.14260 /$ jemds/2018/590

\section{BACKGROUND}

Large bowel is connected with anus by a part of colon called as rectum. The main function of rectum is to store stool. The rectal wall has following layers as follows.

- Mucosa: It is the innermost layer, which is composed of mucus secreting glands.

- Muscularis Propria: This is middle layer containing muscle, which keeps rectum in shape and contract to expel stool.

- Serosa: It is the outermost layer containing loose connective tissue, which prevents friction.

- Mesorectum: The surrounding layer of the rectum which contains fatty tissue.

Other than these 3 layers, rectum is surrounded by lymph nodes, which are called as regional lymph nodes, which are important in clearing harmful organisms and materials from body. Like rectum every organ in the body is surrounded by lymph nodes. $(1,2,3,4,5,6,7,8,9)$

'Financial or Other Competing Interest': None.

Submission 12-04-2018, Peer Review 05-05-2018,

Acceptance 11-05-2018, Published 21-05-2018.

Corresponding Author:

Dr. Avinash Kumar Gautam

\#123, Geeta Nagar, Indore,

Madhya Pradesh, India.

E-mail: gautamavinash50@yahoo.com

DOI: $10.14260 /$ jemds $/ 2018 / 590$

\section{(c) (1) $(9)$}

Adenocarcinoma is the most common cancer of rectum arising from mucosa. Same as colonic cancers rectal carcinoma treatment depends on depth of invasion of cancer into rectal wall and surrounding lymph nodes.

After resection of rectal cancer, loco-regional recurrence is associated with severe debilitating symptoms and is difficult to treat. With median survival of $12-18$ months, the prognosis after a local recurrence is not good.

Patient with rectal cancer have shown improved outcome with adjuvant chemoradiotherapy. In patients with locally advanced rectal carcinoma, overall survival and local control both improves when postoperative chemoradiotherapy is given in comparison to surgery alone.

In our study, we made a protocol for treatment of locally advanced carcinoma rectum in MGM and MY Hospital.

\section{Aims and Objectives}

The study was done in MGM Medical College and MY Hospital, Indore- patients were studied in prospective groups of locally advanced carcinoma rectum with the following aims and objectives-

1. The aim of this study is use of protocol 2012 for management and treatment of locally advanced carcinoma rectum to predict the outcome and prognosis of such patient using this protocol.

\section{MATERIALS AND METHODS}

This is a prospective study of all patients with locally advanced carcinoma rectum seen at MY and Cancer Hospital, Indore. 
Detailed clinical assessment (history and physical examination) was done in all patients. TNM classification was used for final classification.

Eligibility criteria included histopathologically confirmed adenocarcinoma with the inferior margin within $16 \mathrm{~cm}$ from the anal verge. Endorectal ultrasonography and computed tomographic (CT) scanning of the abdomen and pelvis were performed to rule out TNM stage tumours and distant metastases. Patients excluded were older than 75 years of age or who were having previous cancer or who had received chemotherapy or radiotherapy to the pelvis or were contraindicated to chemoradiotherapy.

Two years survival was estimated. The patient had different types of surgical operation and postoperative chemoradiotherapy. Immediate definitive resection and accurate pathological information before beginning ionising radiation are the advantages of postoperative radiotherapy. After study data was statistically analysed by using Fisher's exact test. MYH protocol 2012 for Management of Locally Advanced Carcinoma Rectum.(10,11,12)

\section{Before Surgery}

1. CEA Level.

2. Digital Rectal Examination.

3. Colonoscopy.

4. CECT Abdomen and Pelvic.

5. Routine Investigation.

\section{After Surgery}

1. Adjuvant Chemoradiotherapy.

2. CEA Level.

\section{Follow-Up}

This includes follow-up visits at 3, 6, 12, 18, 24 months after surgery.

\section{Working Proforma}

Name of the patient:

Age:

Sex:

Address:

Symptoms:

Diagnosis:

Chest x-ray:

USG abdomen:

$\mathrm{CT}$ abdomen and pelvis:

$\mathrm{Hb} \%$ :

Pre-operative CEA:

Proctoscopy and colonoscopy:

Intraoperative finding:

Histopathology report:

Post-operative CEA:

\section{RESULTS}

\begin{tabular}{|c|c|c|c|}
\hline Sl. No. & Name of Operation & No. of Patients & \% \\
\hline 1 & APR & 15 & 33.33 \\
\hline 2 & Ant. Resection & 10 & 22.22 \\
\hline 3 & Lap and Colostomy & 20 & 44.44 \\
\hline \multicolumn{3}{|c|}{ Table 1. Types of Operation } \\
\hline
\end{tabular}

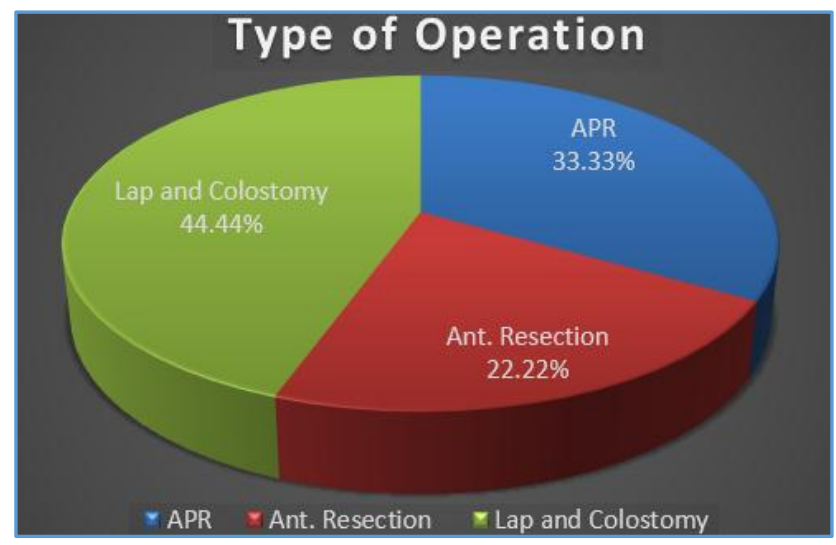

\begin{tabular}{|c|c|c|}
\hline Sl. No. & Age Range & Frequency \\
\hline 1. & $20-29$ & 3 \\
\hline 2. & $30-39$ & 8 \\
\hline 3. & $40-49$ & 11 \\
\hline 4. & $50-59$ & 7 \\
\hline 5. & $60-69$ & 11 \\
\hline 6. & 70 and above & 5 \\
\hline Table 2. Age distribution of Patient with Rectal Cancer \\
\hline
\end{tabular}

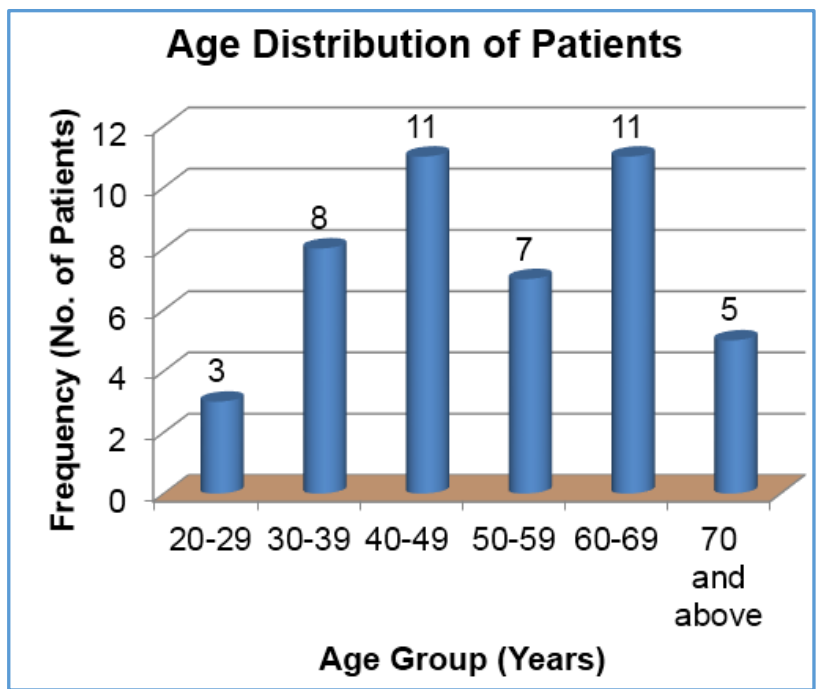

\begin{tabular}{|c|c|c|c|c|}
\hline Sl. No. & APR & $\begin{array}{c}\text { Ant. } \\
\text { Resection }\end{array}$ & $\begin{array}{c}\text { Not } \\
\text { Resectable }\end{array}$ \\
\hline 1. & Alive & 9 & 10 & 8 \\
\hline 2. & Died & 6 & 0 & 12 \\
\hline 3. & $\begin{array}{c}\text { Lost for } \\
\text { Follow-Up }\end{array}$ & 0 & 0 & 0 \\
\hline \multicolumn{4}{|c|}{ Table 3. 2-Year Survival of Patient with Rectal Cancer } \\
\hline
\end{tabular}




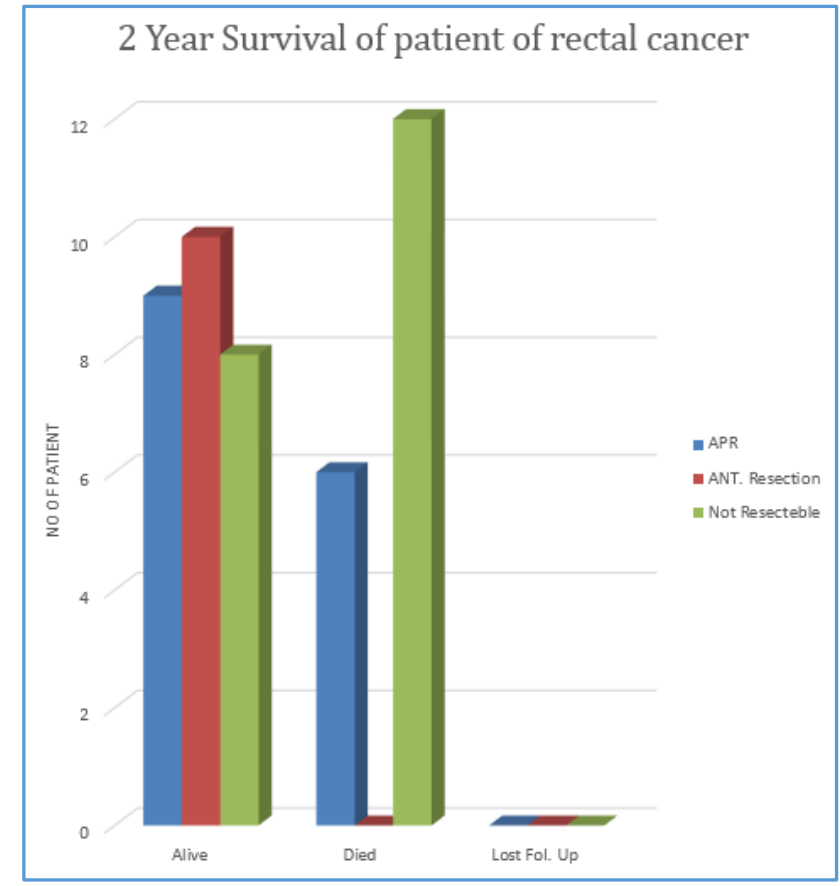

\begin{tabular}{|c|c|c|c|c|}
\hline \multirow{2}{*}{ Sl. No. } & \multirow{2}{*}{ Stage } & Operation & \multicolumn{2}{|c|}{ Site in the Rectum } \\
\cline { 3 - 5 } & & $\begin{array}{c}\text { 10 cm from } \\
\text { Anal Verge }\end{array}$ & $\begin{array}{c}\text { 10 cm from } \\
\text { Anal Verge }\end{array}$ \\
\hline \multirow{2}{*}{1} & & APR & 5 & 0 \\
\cline { 2 - 5 } & & AR & 0 & 5 \\
\hline \multirow{2}{*}{2} & & APR & 10 & 0 \\
\cline { 2 - 5 } 3 & 4 & AR & 0 & 5 \\
\hline \multirow{2}{*}{ Lap. } & 16 & 4 \\
\hline \multicolumn{4}{|c|}{ Colostomy } & 4. Types of Operation based on Site and Stage of \\
Rectal Cancer
\end{tabular}

\section{RESULTS}

Between January 2011 and October 2012, 45 patients with rectal cancer were seen at MY and Cancer Hospital, Indore. Their age range was 20 - 75 years. The male/ female ratio was 1.3: 1 .

The clinical presentation included weight loss, rectal bleeding, altered bowel habit (alternating diarrhoea, diarrhoea, constipation, low back and pelvic pain and tenesmus). The duration of symptoms ranged from 4 weeks 1 year. Thirty patients, i.e. $66 \%$ approached within 6 months of starting of the symptoms and about $34 \%$ after 6 months of starting of the symptoms.

Forty-five (100\%) had one form of definitive surgical operation had histopathologic confirmation of their rectal lesion on biopsy as adenocarcinoma. Of the 45 patients who had definitive operation, 15 had abdominoperineal (AP) resection, 10 had anterior resection and 20 had tumours that were not resectable. AP resection was used for patients with lesions less than $10 \mathrm{~cm}$ from the anal verge, whereas anterior resection was used for patients with lesions $10 \mathrm{~cm}$ or more from the anal verge.(13-44)

9 of the 15 patients $(60 \%)$ who had AP resection are alive till date, 6 died, while 10 out of 10 who had anterior resection $(100 \%)$ are alive till date. For patients who had non-resectable tumours, 12 died within 6 months of diagnosis. Only 8 out of $20(40 \%)$ of non-resectable tumours were alive at 2 years. None of the patients had preoperative chemoradiotherapy. All of them had adjuvant chemotherapy (5-fluorouracil) and radiotherapy.(45-50)

\section{DISCUSSION}

After carcinoma of the lung and stomach in male and after breast and cervical cancer in female, the third most common malignant neoplasm is colorectal carcinoma. It accounts for $9.2 \%$ in females and $8.8 \%$ of cancers in males. In Western communities like USA, England and Wales, it is more common. Patients with rectal cancer has shown improvement with Adjuvant radiotherapy with chemotherapy. Postoperative chemoradiotherapy significantly improves both local control and overall survival as compared with surgery alone or surgery plus irradiation in locally advanced disease. This information prompted a National Institute of Health consensus conference, convened in 1990, to recommend postoperative adjuvant chemoradiotherapy as standard treatment for patients with rectal cancer classified as tumour-nodemetastasis (TNM) stage II (i.e. a tumour penetrating the rectal wall without regional lymph node involvement) or stage III (i.e. any tumour with regional lymph node involvement).

If there was no macroscopic residual tumour once resection has been done, it is considered as curative resection and if there is presence of distant metastases or tumour not resected with proper clearance, then was considered palliative. Due to delayed presentation, our patients were having lower resection rates. This situation can be handled with health education with easily accessible, acceptable and affordable health care.(51-76)

Though follow-up is poor in our set-up because of unawareness and inadequate education of patients, it is found to be better in patients who had AP resection and permanent colostomy may be due to colostomy related problems.

Best treatment patients were offered was a palliative treatment only, because many patients in our study presented with advanced tumour. As described by Lockhart-Mummery in 1958, palliative treatment is required when "to the surgeon's knowledge or belief growth has been left in the body, whether this is in the lungs, liver, posterior abdominal wall, pelvic or inguinal glands."

\section{CONCLUSION}

Patient with advanced rectal cancer should receive postoperative chemoradiotherapy. Local control, distant spread and survival improves when postoperative radiation therapy is combined with chemotherapy.

We did not give preoperative chemoradiotherapy because of possible overtreatment of early stage tumours, impaired wound healing and pelvic fibrosis increasing the risk of operative complications and also because of ignorance and illiteracy about the disease and poor follow-up. Postoperative chemoradiotherapy gives advantage of immediate definitive resection and accurate pathological staging of the resected tumour and lymph nodes and avoids the wound healing problems associated with preoperative radiation.

With the present study, we aim to definitely clarify the role of the different postoperative therapy regimen in rectal cancer concerning local control as well as long-term toxicities and overall survival. 


\section{REFERENCES}

[1] Giovannucci E, Wu K. Cancers of the colon and rectum. In: Schottenfeld D, Fraumeni J, eds. Cancer. Epidemiology and prevention. $3^{\text {rd }}$ edn. New York: Oxford University Press 2006.

[2] American Cancer Society. Cancer facts \& figures, 2010. American Cancer Society. http://www.cancer.org/Research/CancerFactsFigures / index. Accessed April 26, 2011.

[3] Anagnostopoulos G, Sakorafas GH, Kostopoulos P, et al. Squamous cell carcinoma of the rectum: a case report and review of the literature. Eur J Cancer Care (Engl) 2005;14(1):70-4.

[4] Potter JD. Colorectal cancer: molecules and populations. J Natl Cancer Inst 1999;91(11):916-32.

[5] Leggett BA, Devereaux B, Biden K, et al. Hyperplastic polyposis: association with colorectal cancer. Am J Surg Pathol 2001;25(2):177-84.

[6] Wheeler JM, Bodmer WF, Mortensen NJ. DNA mismatch repair genes and colorectal cancer. Gut 2000;47(1):148-53.

[7] Mak RH, McCarthy EP, Das P, et al. Adoption of preoperative radiation therapy for rectal cancer from 2000 to 2006: a surveillance, epidemiology and end results patterns-of-care study. Int J Radiat Oncol Biol Phys 2011;80(4):978-84.

[8] Rothwell PM, Fowkes GR, Belch JF, et al. Effect of daily aspirin on long term risk of death due to cancer: analysis of individual patient data from randomized trials. Lancet Dec 7/2010. Early online publication.

[9] Burn J, Gerdes AM, Macrae F, et al. Long-term effect of aspirin on cancer risk in carriers of hereditary colorectal cancer: an analysis from the CAPP2 randomised controlled trial. Lancet 2011;378(9809):2081-7.

[10] Rothwell PM, Price JF, Fowkes FG, et al. Short-term effects of daily aspirin on cancer incidence, mortality and non-vascular death: analysis of the time course of risks and benefits in 51 randomised controlled trials. Lancet 2012;379(9826):1602-12.

[11] Yothers G, Sargent DJ, Wolmark N, et al. Outcomes among black patients with stage II and III colon cancer receiving chemotherapy: an analysis of ACCENT adjuvant trials. J Natl Cancer Inst 2011;103(20):1498506.

[12] Robbins AS, Siegel RL, Jemal A. Racial disparities in stage-specific colorectal cancer mortality rates from 1985 to 2008. J Clin Oncol 2012;30(4):401-5.

[13] Johns LE, Houlston RS. A systematic review and metaanalysis of familial colorectal cancer risk. Am J Gastroenterol 2001;96(10):2992-3003.

[14] Burt RW. Familial risk and colorectal cancer. Gastroenterol Clin North Am 1996;25(4):793-803.

[15] United States Preventive Services Task Force. Screening for colorectal cancer. AHRQ: Agency for Healthcare Research and Quality. http://www.uspreventiveservicestaskforce.org/uspstf /uspscolo.htm. Accessed July 15, 2009.

[16] De Wijkerslooth TR, Stoop EM, Bossuyt PM, et al. Immunochemical fecal occult blood testing is equally sensitive for proximal and distal advanced neoplasia. Am J Gastroenterol 2012;107(10):1570-8.
[17] Nelson H, Petrelli N, Carlin A, et al. Guidelines 2000 for colon and rectal cancer surgery. J Natl Cancer Inst 2001;93(8):583-96.

[18] Schoen RE, Pinsky PF, Weissfeld JL, et al. Colorectalcancer incidence and mortality with screening flexible sigmoidoscopy. N Engl J Med 2012;366(25):2345-57.

[19] Brounts LR, Lehmann RK, Lesperance KE, et al. Improved rates of colorectal cancer screening in an equal access population. Am J Surg 2009;197(5):60912: discussion 612-3.

[20] Meredith KL, Hoffe SE, Shibata D. The multidisciplinary management of rectal cancer. Surg Clin North Am 2009;89(1):177-215, ix-X.

[21] Kapiteijn E, Marijnen CA, Nagtegaal ID, et al. Preoperative radiotherapy combined with total mesorectal excision for resectable rectal cancer. $\mathrm{N}$ Engl J Med 2001;345(9):638-46.

[22] Baxter NN, Garcia-Aguilar J. Organ preservation for rectal cancer. J Clin Oncol 2007;25(8):1014-20.

[23] Rothenberger D, Garcia-Aquilar J. Rectal cancer, local treatment. In: Current therapy in colon and rectal surgery. $2^{\text {nd }}$ edn. Philadelphia, Pa: Mosby 2005.

[24] Peng J, Chen W, Venook AP, et al. Long-term outcome of early-stage rectal cancer undergoing standard resection and local excision. Clin Colorectal Cancer 2011;10(1):37-41.

[25] Weiser MR, Landmann RG, Wong WD, et al. Surgical salvage of recurrent rectal cancer after transanal excision. Dis Colon Rectum 2005;48(6):1169-75.

[26] Bullard KM, Rothenberger DA. Colon, rectum and anus. In: Schwartz SE, edr. Principles of surgery. $8^{\text {th }}$ edn. New York, NY: McGraw Hill 2005.

[27] Li S, Chi P, Lin $\mathrm{H}$, et al. Long-term outcomes of laparoscopic surgery versus open resection for middle and lower rectal cancer: an NTCLES study. Surg Endosc 2011;25(10):3175-82.

[28] Van Helmond J, Beart RW. Cancer of the rectum: operative management and adjuvant therapy. In: Current therapy in colon and rectal surgery. $2^{\text {nd }}$ edn. Philadelphia, Pa: Mosby 2005.

[29] Maurer CA, Renzulli P, Kull C, et al. The impact of the introduction of total mesorectal excision on local recurrence rate and survival in rectal cancer: long-term results. Ann Surg Oncol 2011;18(7):1899-906.

[30] Fujita S, Akasu T, Mizusawa J, et al. Postoperative morbidity and mortality after mesorectal excision with and without lateral lymph node dissection for clinical stage II or stage III lower rectal cancer (JCOG0212): results from a multicentre, randomised controlled, non-inferiority trial. Lancet Oncol 2012;13(6):616-21.

[31] Dhir M, Lyden ER, Wang A, et al. Influence of margins on overall survival after hepatic resection for colorectal metastasis: a meta-analysis. Ann Surg 2011;254(2):234-42.

[32] Margalit DN, Mamon HJ, Ancukiewicz M, et al. Tolerability of combined modality therapy for rectal cancer in elderly patients aged 75 years and older. Int J Radiat Oncol Biol Phys 2011;81(5):e735-41.

[33] Ceelen W, Fierens K, Van Nieuwenhove Y, et al. Preoperative chemoradiation versus radiation alone for stage II and III resectable rectal cancer: a systematic review and meta-analysis. Int J Cancer 2009;124(12):2966-72. 
[34] Jakobsen A, Ploen J, Vuong T, et al. Dose-effect relationship in chemoradiotherapy for locally advanced rectal cancer: a randomized trial comparing two radiation doses. Int J Radiat Oncol Biol Phys 2012;84(4):949-54.

[35] Wong RK, Tandan V, De Silva S, et al. Pre-operative radiotherapy and curative surgery for the management of localized rectal carcinoma. Cochrane Database Syst Rev 2007;(2):CD002102.

[36] Ng K, Ogino S, Meyerhardt JA, et al. Relationship between statin use and colon cancer recurrence and survival: results from CALGB 89803. J Natl Cancer Inst 2011;103(20):1540-51.

[37] NCCN. Clinical Practice Guidelines in oncology symposium: colon, rectal and anal cancers. http://cme.medscape.com/viewprogram/8374.

[38] NCCN. Clinical Practice Guidelines in Oncology. Rectal Cancer. Vol. 2009. http://www.nccn.org/professionals/physician_gls/ PDF/rectal.pdf.Accessed May 2009.

[39] Kidwell KM, Yothers G, Ganz PA, et al. Long-term neurotoxicity effects of oxaliplatin added to fluorouracil and leucovorin as adjuvant therapy for colon cancer: results from national surgical adjuvant breast and bowel project trials C-07 and LTS-01. Cancer 2012;118(22):5614-22.

[40] Cao S, Bhattacharya A, Durrani FA, et al. Irinotecan, oxaliplatin and raltitrexed for the treatment of advanced colorectal cancer. Expert Opinion on Pharmacotherapy 2006;7(6):687-703.

[41] Maughan TS, Adams RA, Smith CG, et al. Addition of cetuximab to oxaliplatin-based first-line combination chemotherapy for treatment of advanced colorectal cancer: results of the randomised phase 3 MRC COIN trial. Lancet 2011;377(9783):2103-14.

[42] Douillard JY, Siena S, Cassidy J, et al. Randomized, phase III trial of panitumumab with infusional fluorouracil, leucovorin, and oxaliplatin (FOLFOX4) versus FOLFOX4 alone as first-line treatment in patients with previously untreated metastatic colorectal cancer: the PRIME study. J Clin Oncol 2010;28(31):4697-705.

[43] Peeters M, Price TJ, Cervantes A, et al. Randomized phase III study of panitumumab with fluorouracil, leucovorin and irinotecan (FOLFIRI) compared with FOLFIRI alone as second-line treatment in patients with metastatic colorectal cancer. J Clin Oncol 2010;28(31):4706-13.

[44] Simkens LH, Koopman M, Mol L, et al. Influence of body mass index on outcome in advanced colorectal cancer patients receiving chemotherapy with or without targeted therapy. Eur J Cancer 2011;47(17):2560-7.

[45] Chao A, Thun MJ, Connell CJ, et al. Meat consumption and risk of colorectal cancer. JAMA 2005;293(2):17282.

[46] Baron JA, Beach M, Mandel JS, et al. Calcium supplements for the prevention of colorectal adenomas. Calcium Polyp Prevention Study Group. N Engl J Med 1999;340(2):101-7.

[47] Ferrari P, Jenab M, Norat T, et al. Lifetime and baseline alcohol intake and risk of colon and rectal cancers in the European prospective investigation into cancer and nutrition (EPIC). Int J Cancer 2007;121(9):2065-72.
[48] Kabat GC, Howson CP, Wynder EL. Beer consumption and rectal cancer. Int J Epidemiol 1986;15(4):494-501.

[49] Tsoi KK, Pau CY, Wu WK, et al. Cigarette smoking and the risk of colorectal cancer: a meta-analysis of prospective cohort studies. Clin Gastroenterol Hepatol 2009;7(6):682-688.e1-5.

[50] Phipps AI, Baron J, Newcomb PA. Prediagnostic smoking history, alcohol consumption and colorectal cancer survival: The Seattle Colon Cancer Family Registry. Cancer 2011;117(21):4948-57.

[51] Quan D, Gallinger S, Nhan C, et al. The role of liver resection for colorectal cancer metastases in an era of multimodality treatment: a systematic review. Surgery 2012;151(6):860-70.

[52] Cheng X, Chen VW, Steele B, et al. Subsite-specific incidence rate and stage of disease in colorectal cancer by race, gender and age group in the United States, 1992-1997. Cancer 2001;92(10):2547-54.

[53] Ebert MP, Tanzer M, Balluff B, et al. TFAP2E-DKK4 and chemoresistance in colorectal cancer. $\mathrm{N}$ Engl J Med 2012;366(1):44-53.

[54] Hendlisz A, van den Eynde M, Peeters M, et al. Phase III trial comparing protracted intravenous fluorouracil infusion alone or with yttrium-90 resin microspheres radioembolization for liver-limited metastatic colorectal cancer refractory to standard chemotherapy. J Clin Oncol 2010;28(23):3687-94.

[55] Nielsen A, Munk C, Kjaer SK. Trends in incidence of anal cancer and high-grade anal intraepithelial neoplasia in Denmark, 1978-2008. Int J Cancer 2012;130(5):116873.

[56] Thong MS, Mols F, Lemmens VE, et al. Impact of preoperative radiotherapy on general and diseasespecific health status of rectal cancer survivors: a population-based study. Int J Radiat Oncol Biol Phys 2011;81(3):e49-58.

[57] Bipat S, Glas AS, Slors FJ, et al. Rectal cancer: local staging and assessment of lymph node involvement with endoluminal US, CT and MR imaging--a metaanalysis. Radiology 2004;232(3):773-83.

[58] Kumar A, Scholefield JH. Endosonography of the anal canal and rectum. World J Surg 2000;24(2):208-15.

[59] Lipton LR, Johnson V, Cummings C, et al. Refining the Amsterdam Criteria and Bethesda Guidelines: testing algorithms for the prediction of mismatch repair mutation status in the familial cancer clinic. J Clin Oncol 2004;22(24):4934-43.

[60] Lynch HT, de la Chapelle A. Hereditary colorectal cancer. N Engl J Med 2003;348(10):919-32.

[61] Phang PT, Wong WD. Preoperative evaluation of the rectal cancer patient: assessment of operative risk and strategy. In: Current therapy in colon and rectal strategy. $2^{\text {nd }}$ edn. Philadelphia, Pa: Mosby 2005.

[62] Robert Koch-Institut (Hrsg) und die Gesellschaft der epidemiologischen Krebsregister in Deutschland e.V. (Hrsg) Krebs in Deutschland 2003 - 2004. Häufigkeiten und Trends. 6. Überarbeitete Auflage. Berlin 2008.

[63] NIH consensus conference. Adjuvant therapy for patients with colon and rectal cancer. JAMA 1990;264(11):1444-50. 
[64] Camma C, Giunta M, Fiorica F, et al. Preoperative radiotherapy for resectable rectal cancer: a metaanalysis. JAMA 2000;284(8):1008-15.

[65] Swedish Rectal Cancer Trial, Cedermark B, Dahlberg M, et al. Improved survival with preoperative radiotherapy in resectable rectal cancer. $\mathrm{N}$ Engl J Med 1997;336(14):980-7.

[66] Sauer R, Becker H, Hohenberger W, et al. Preoperative versus postoperative chemoradiotherapy for rectal cancer. N Engl J Med 2004;351(17):1731-40.

[67] Heald RJ, Moran BJ, Ryall RD, et al. Rectal cancer: the Basingstoke experience of total mesorectal excision, 1978-1997. Arch Surg 1998;133(8):894-9.

[68] Bosset JF, Collette L, Calais G, et al. Chemotherapy with preoperative radiotherapy in rectal cancer. $\mathrm{N}$ Engl J Med 2006;355(11):1114-23.

[69] Bujko K, Nowacki MP, Nasierowska-Guttmejer A, et al. Long-term results of a randomized trial comparing preoperative short-course radiotherapy with preoperative conventionally fractionated chemoradiation for rectal cancer. $\mathrm{Br} \mathrm{J}$ Surg 2006;93(10):1215-23.
[70] Kachnic LA, Hong TS, Ryan DP. Rectal cancer at the crossroads: the dilemma of clinically staged T3, N0, M0 disease. J Clin Oncol 2008;26(3):350-1.

[71] Kauermann G. Penelized spline smoothing in multivariable survival models with varying coefficients. Computational Statistics and Data Analysis 2005;49(1):169-86.

[72] O'Brien PC, Fleming TR. A multiple testing procedure for clinical trials. Biometrics 1979;35(3):549-56.

[73] Taves DR. Minimization: a new method of assigning patients to treatment and control groups. Clin Pharmacol Ther 1974;15(5):443-53.

[74] Widder J, Sedlmayer F, Stanek C, et al. Quality assurance in preoperative radiotherapy of rectal cancer: evaluation of a pre-trial dummy-run. Radiother Oncol 2000;56(3):341-7.

[75] Quirke P. The pathologist, the surgeon and colorectal cancer get it right because it matters. Prog Pathol 1998;4:201-13.

[76] Dworak 0, Keilholz L, Hoffmann A. Pathological features of rectal cancer after preoperative radiochemotherapy. Int J Colorectal Dis 1997;12(1):1923. 